\title{
Forensic Images: Mascagni's Plate of the Internal Mammary Lymph Nodes
}

\section{Wilson IB Onuigbo*}

Department of Pathology, Medical Foundation and Clinic, Enugu, Nigeria

"Corresponding author: Wilson IB Onuigbo, Department of Pathology, Medical Foundation and Clinic, 8 Nsukka Lane, Enugu 40001, Nigeria, E-mail: wilson.onuigbo@gmail.com

Rec date: August 15, 2015 Acc date: August 18, 2015 Pub date: August 24, 2015

Copyright: $\odot 2015$ Onuigbo WIB. This is an open-access article distributed under the terms of the Creative Commons Attribution License, which permits unrestricted use, distribution, and reproduction in any medium, provided the original author and source are credited.

\section{Image Article}

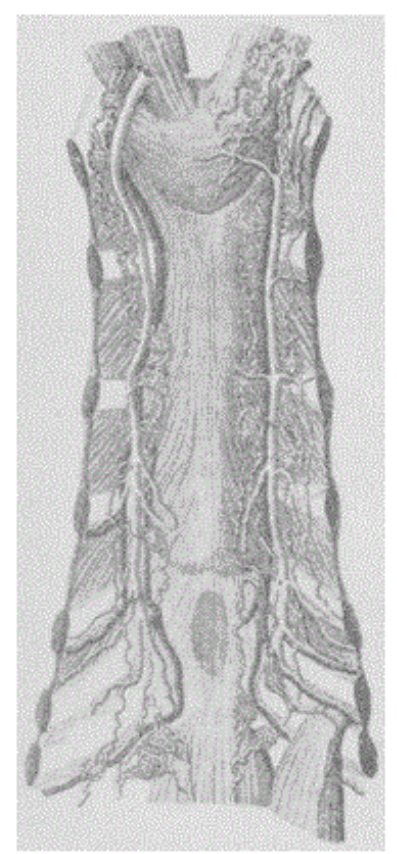

Figure 1: Mascagni's plate of the internal mammary lymph nodes, published in Siena, 1787.

Published in Siena in 1787 was a plate made by Mascagni in Siena [1]. It was reproduced by Richard Handley [2] in a Presidential address containing a brief history of the internal mammary lymph nodes (Figure 1).
When were these nodes first recognized? Elsewhere, [3] I showed that such firsts in the cancer literature were often false! In this context, Handley stated that "The first mention of them in English was by W. C. Cruikshank and he is generally credited as being their discoverer in the English-speaking world." [2].

Incidentally, it is noteworthy that Cruikshank had worked with John Hunter in his London School of Anatomy. Not surprisingly, his own master knew of this phenomenon as shown in his lectures made during 1786 and 1787, and "taken in short-hand by Mr Nathaniel Rumsey." [4].

In conclusion, I am persuaded that, perhaps, the better word to use should be not "first" but "early." [5,6]. Incidentally, William Harvey [7] wrote on 28th April, 1652, with regard to such priority claims as follows: "why may not the thoughts, opinions, and manners now prevalent, many years hence return again, after an intermediate period of neglect"? Consequently, literature searches ought to be given more stringent attention than had hitherto been undertaken.

\section{References}

1. Mascagni's plate of the internal mammary lymph nodes (1972) Published in Siena 1787. Proc Roy Soc Med 65: 438.

2. Handley RS (1972) Observations and thoughts on cancer of the breast. Proc Roy Soc Med 65: 437-439.

3. Onuigbo WIB (1971) False firsts in cancer literature. Oncology 25: 163-167.

4. The works of John Hunter (1835) J. F. Palmer, London 1: 201.

5. Onuigbo WIB (2005) Early descriptions of Krukenberg tumors. J Am Coll Surg 200: 111-112.

6. Onuigbo WIB (2005) Early description of cancer to cancer metastasis in 1848. NZ Med J 118.

7. The works of William Harvey (1847) (translated by R. Willis) 582. London. 